\title{
Introduction: Atwood at 80
}

When Margaret Atwood celebrated her 80th birthday in November 2019, there was a feeling that the occasion called for a burst of applause - figuratively speaking. Around Europe, many Canadian scholars and Canadian Studies Associations responded with a range of activities. Slovenia contributed handsomely: first, with an event at the Univerzitetna knjižnica Maribor - Fourscore and More: Margaret Atwood at Eighty - and second, with this special issue dedicated to Atwood's recent work.

With a tight deadline for submissions, we were lucky to have the cooperation of a conference: Margaret Atwood 80: Central European Interpretations / Margaret Atwood 80: interprétations de l'evre en Europe Centrale, which was jointly sponsored by Károli Gáspár University of The Reformed Church In Hungary, Pázmány Péter Catholic University and Eötvös Loránd University. The organisers graciously included ELOPEs Call for Papers in their programme, and several of the papers published here originated from that initiative.

Atwood herself found the time to help open the conference (virtually) with a few words "Wait a minute! 80? What happened? Just the other day I was 77! Where did the time go?" - and some illustrations of her "Writing Burrow," as well as of illustrations depicting her need to turn down some invitations and requests for interviews.

Originally, the editors envisioned a concentration on Atwood's 21st-century works; however, this worthy objective gave way under the cultural dominance of The Handmaid's Tale, Atwood's 1985 novel. Given the recent appearance of its sequel, The Testaments (2019), the pair of novels inevitably garnered considerable critical attention (not to mention a Booker Prize for the latter).

Contributors to this issue range from young scholars at the beginning of their careers, to experienced scholars who have devoted much of their careers to Atwood. Both voices are welcome and show the long-lasting relevance of Atwood's oeuvre.

Coral Ann Howells' overview of the later Atwood reminds us that Atwood continues to reinvent herself as a writer. Her literary output in recent decades has been wide-ranging, and the articles collected here bear witness to this range, even if Atwood the poet, Atwood the non-fiction writer, Atwood the children's author, and Atwood the comic book author are not present.

Though some of the articles collected here focus on the red-clad handmaids and the world of Gilead, others look to perhaps lesser-known Atwood creations. In addition to a postcolonial approach to Atwood's Cat's Eye, there is a consideration of Atwood as a postmodern myth-rewriter in The Penelopiad, Atwood as the creator of MaddAddam's post-apocalyptic world, along with a paper highlighting the challenges of translating Atwood's deceptively straightforward prose, and, finally, an examination of Atwood the illustrator. 
The editors wish to thank all those whose silent contributions made this special issue possible: the translators - Tjaša Mohar, Tina Ritlop, Tadeja Tement, Tadej Todorović and Simon Zupan - and the journal editors - Andrej Stopar and Mojca Krevel.

Michelle Gadpaille, University of Maribor, Slovenia

Jason Blake, University of Ljubljana, Slovenia

Guest Editors of ELOPE Vol. 17, No. 1 (2020) 